\title{
Endocrine therapy resistance can be associated with high estrogen receptor $\alpha$ $(E R \alpha)$ expression and reduced ER $\alpha$ phosphorylation in breast cancer models
}

\author{
Barbara Kuske ${ }^{1}$, Catherine Naughton ${ }^{1}$, Kate Moore ${ }^{1}$, Kenneth G MacLeod ${ }^{1}$, \\ William R Miller ${ }^{1}$, Robert Clarke ${ }^{2}$, Simon $P$ Langdon $^{1}$ and David A Cameron ${ }^{1}$ \\ ${ }^{1}$ CRUK Cancer Research Centre and Academic Breast Unit, University of Edinburgh, Crewe Road South, Edinburgh EH4 2XR, UK, \\ ${ }^{2}$ Department of Oncology, Georgetown University, Washington, District of Columbia, USA \\ (Requests for offprints should be addressed to S P Langdon; Email: simon.langdon@ cancer.org.uk) \\ B Kuske and C Naughton contributed equally to this work.
}

\begin{abstract}
Hormone-dependent estrogen receptor (ER)-positive breast cancer cells may adapt to low estrogen environments such as produced by aromatase inhibitors. In many instances, cells become insensitive to the effects of estrogen but may still retain dependence on ER. We have investigated the expression, function, and activation of ER $\alpha$ in two endocrine-resistant MCF-7 models to identify mechanisms that could contribute to resistance. While MCF-7/LCC1 cells are partially estrogen dependent, MCF-7/LCC9 cells are fully estrogen insensitive and fulvestrant and tamoxifen resistant. In both MCF-7/LCC1 and MCF-7/LCC9 cell lines, high expression of ER $\alpha$ was associated with enhanced binding to the trefoil factor 1 (TFF1) promoter in the absence of estrogen and increased transcription of TFF1 and progesterone receptor. In contrast to the observations derived from hypersensitive and supersensitive models, these cells were truly estrogen independent; nevertheless, removal of ER $\alpha$ by siRNA, or fulvestrant, a specific ER downregulator, inhibited growth indicating dependence on ER $\alpha$. In the absence of estrogen, neither ER $\alpha$ Ser $^{118}$ nor Ser ${ }^{167}$ were phosphorylated as frequently found in other ligandindependent cell line models. Addition of estrogen activated ER $\alpha \operatorname{Ser}^{118}$ in MCF-7 and LCC 1 cells but not in LCC9 cells. We suggest that the estrogen-independent growth within these cell lines is accounted for by high levels of $\mathrm{ER} \alpha$ expression driving transcription and full estrogen independence explained by lack of ER $\alpha$ activation through $\mathrm{Ser}^{118}$.
\end{abstract}

Endocrine-Related Cancer (2006) 13 1121-1133

\section{Introduction}

Estrogen receptor $\alpha(E R \alpha)$ is a major growth regulator for many breast cancers and has provided an exploitable target for therapy (Ali \& Coombes 2002). Estrogen binding to $\mathrm{ER} \alpha$ promotes conformational changes in the receptor leading to dimerization and attachment to DNA, generally at the site of conserved estrogen response elements in the promoter regions of target genes (Ali \& Coombes 2002). Functional regulation of $\mathrm{ER} \alpha$ is additionally mediated via phosphorylation of key residues in the activation function 1 (AF-1) domain of ER $\alpha$ including $\mathrm{Ser}^{118}$ and $\operatorname{Ser}^{167}$ and these influence both DNA binding and recruitment of cofactor molecules (reviewed in Lannigan 2003). The activation of ER involves crosstalk with other growth factor-signaling pathways. There is extensive evidence that activation of the mitogen-activated protein kinase (MAPK)-signaling cascade and the phosphoinositol 3 kinase (PI3-K) pathway phosphorylate $\mathrm{ER} \alpha$ at $\operatorname{Ser}^{118}$ and $\operatorname{Ser}^{167}$, via extracellular signal-regulated kinase (ERK)1/2 and Akt respectively (Bunone et al. 1996, Martin et al. 2000, Lannigan 2003). Transcriptional activation of ER $\alpha$ then involves a dynamic process where large transcription complexes incorporating co-activator proteins are assembled in an ordered and combinatorial manner 
(Glass \& Rosenfeld 2000, Metivier et al. 2003). Well-defined estrogen-regulated genes include trefoil factor 1 (TFF1)/pS2 (Masiakowski et al. 1982, Jakowlew et al. 1984) and progesterone receptor (PGR; Nardulli et al. 1988).

While tamoxifen has been the established form of treatment for ER-positive breast cancers for more than 20 years, other anti-estrogen strategies, notably aromatase inhibitors (Johnston \& Dowsett 2003) and selective estrogen downregulators (SERDs), are increasingly being used (Robertson 2002). Despite initial responsiveness to these agents, most tumors eventually recur with acquired resistance (Clarke et al. 2001, 2003). Multiple mechanisms, dependent on the form of endocrine treatment, are involved in the development of resistance and, in many cases, these mechanisms remain unclear. During the acquisition of endocrine resistance, progressive changes are frequently observed, with ER-positive breast cancer cells progressing in a stepwise manner from a fully estrogen-sensitive phenotype to an estrogen-sensitive, but no longer dependent phenotype, to a fully resistant phenotype (Clarke et al. 2001, 2003).

With the increasing clinical use of aromatase inhibitors, such as letrozole, anastrazole, and exemestane which act by inhibiting estrogen synthesis (Johnston \& Dowsett 2003), there has been great interest in how breast cancer cells can adapt to low estrogen environments and become resistant to the effects of these drugs. In most cases of acquired anti-estrogen resistance, expression of $\mathrm{ER} \alpha$ is retained, suggesting that resistance involves either changed functionality or bypass of the receptor. Culturing breast cancer cells in estrogenlow conditions to produce long-term estrogen deprivation (LTED) has identified mechanisms of estrogen hypersensitivity and estrogen supersensitivity (Yue et al. 2002, Martin et al. 2003, 2005a,b, Santen et al. 2005). Estrogen hypersensitivity is characterized by the ability of cells to respond to levels of estrogen at concentrations 2-3 log lower than required to stimulate wild-type cells (Yue et al. 2002, Santen et al. 2005). This mechanism involves increased expression of $\mathrm{ER} \alpha$ alongside enhanced phosphorylation of $\mathrm{ER} \alpha \mathrm{Ser}^{118}$ and is associated with activation of the ERK1/2 and PI3-K pathways. Estrogen supersensitivity, wherein cells are apparently estrogen independent, is a mechanism again associated with enhanced ER $\alpha$ expression, ERK activation, and activation of $\mathrm{ER} \alpha \operatorname{Ser}^{118}$ and involves $\mathrm{ER} \alpha$ being supersensitized by growth factor activation (Martin et al. 2003, 2005a).
While higher levels of ER $\alpha$ expression are generally associated with enhanced estrogen response, in certain cases tumors expressing high levels of $\mathrm{ER} \alpha$ can be insensitive to endocrine manipulation. High levels of ER $\alpha$ expression have been associated with increased proliferation rates (Black et al. 1983) and poor prognosis in breast cancer patients not receiving adjuvant therapy (Black et al. 1983, Thorpe et al. 1993). It has been suggested that a high level of ER $\alpha$ may lead to constitutive activation (Fowler et al. 2004). This mechanism has recently been demonstrated by Fowler et al. (2004, 2006) in a tetracyclineinducible $\mathrm{ER} \alpha$ expression model of the MCF-7 cell line, wherein increased ER $\alpha$ expression resulted in aberrant promoter occupancy and gene activation in the absence of estrogen. The increased receptor activity required the amino-terminal domain and was not inhibited by tamoxifen, supporting the notion of AF-1 activation, yet was independent of $\mathrm{Ser}^{104 / 106}$ and $\mathrm{Ser}^{118}$ phosphorylation (Fowler et al. 2004).

In these models, the expression of ER $\alpha$ is still critical to the response and it has been suggested that use of a SERD such as fulvestrant (faslodex, ICI 182780 ) would be a beneficial strategy once resistance to aromatase inhibitors has developed (Johnston et al. 2005, Martin et al. 2005b). A number of laboratories are developing models of resistance to this agent to identify strategies that might be tried at the onset of resistance (Dowsett et al. 2005, Howell 2005, Johnston et al. 2005, Martin et al. 2005b, Nicholson et al. 2005, Normanno et al. 2005).

We have investigated two MCF-7 cell lines (MCF-7/LCC1 and MCF-7/LCC9), which have acquired estrogen insensitivity and with variable sensitivity to tamoxifen and fulvestrant to identify novel mechanisms of endocrine resistance that might arise in clinical specimens. The wild-type ER-positive MCF-7 breast cancer cell line is both estrogen dependent and responsive to anti-estrogens, such as tamoxifen and fulvestrant. The MCF-7/LCC1 (LCC1) cell line was derived from an MCF-7 xenograft, which had grown in a low estrogen environment in an immuno-deprived mouse and which was known to be estrogen independent but with a degree of estrogen sensitivity (Brunner et al. 1993). Treatment of the cell line with fulvestrant produced the MCF-7/LCC9 (LCC9) cell line which is fully resistant to both estrogen and fulvestrant (Brunner et al. 1997). A number of novel features of these lines were identified within this study and are reported here. 


\section{Materials and methods}

\section{Cell proliferation}

MCF-7 cells were routinely grown in phenol red containing Dulbecco's modified Eagle medium (DMEM) supplemented with 10\% fetal calf serum (FCS), penicillin (100 units $/ \mathrm{ml}$ ), and streptomycin $(100$ (g/ml). LCC1 and LCC9 cells (source: Dr Robert Clarke, V T Lombardi Cancer Research Center, Georgetown University Medical School, Washington, DC, USA) were routinely kept in phenol-free containing DMEM supplemented with 5\% dextranactivated charcoal-stripped fetal calf serum (DCC), penicillin (100 units $/ \mathrm{ml})$, streptomycin $(100(\mathrm{~g} / \mathrm{ml})$, and $2 \mathrm{mM}$ glutamine. All cells were grown at $37^{\circ} \mathrm{C}$ in $5 \% \mathrm{CO}_{2}$. To determine the effects of $17 \beta$-estradiol $\left(\mathrm{E}_{2}\right)$ and tamoxifen on cell proliferation, MCF-7 cells were seeded in six-well plates in phenol red containing DMEM with $10 \%$ fetal bovine serum (FBS) for $24 \mathrm{~h}$. The media were changed to phenol red-free DMEM with $5 \%$ DCC for $48 \mathrm{~h}$. The cells were then supplemented with media containing either $1 \mathrm{nM} \mathrm{E} \mathrm{E}_{2}$, $1 \mu \mathrm{M}$ tamoxifen or both. LCC1 and LCC9 cells were seeded in six-well plates in phenol red-free containing DMEM with 5\% DCC and after $24 \mathrm{~h}$ supplemented with $\mathrm{E}_{2}$ and/or tamoxifen. Cell growth was evaluated using a Coulter counter. Fulvestrant was a kind gift from Dr Alan Wakeling (AstraZeneca, Macclesfield, Cheshire, UK). For studies exploring growth in DMEM without serum, the sulforhodamine-B (SRB) colorimetric assay was used.

Briefly, log phase cells were seeded into 96-well flatbottom tissue culture plates. The following day, cells were washed in PBS and media replaced with phenol red-free DMEM for $48 \mathrm{~h}$. Cells were then treated with concentrations of $E_{2}$ varying from $10 \mathrm{fM}$ to $1 \mu \mathrm{M}$ in the absence or presence of $100 \mathrm{nM}$ fulvestrant. After $72 \mathrm{~h}$, plates were removed from the incubator and ice-cold 25\% trichloroacetic acid (TCA) solution $(50 \mu \mathrm{l})$ added to each well. All plates were placed on ice for $60 \mathrm{~min}$ after which the TCA solution was removed. The plates were washed under running water and dried prior to staining with SRB dye solution (30 min at room temperature) and the trays were washed with $1 \%$ glacial acetic acid $(\times 4)$ at room temperature, air-dried, and resuspended in $10 \mathrm{mM}$ Tris buffer $(\mathrm{pH} 10.5 ; 150 \mu \mathrm{l})$ before reading at $540 \mathrm{~nm}$.

\section{RNA extraction and RT-PCR}

Extraction of total RNA from whole cells was performed using Tri-Reagent (Sigma) as per the manufacturers' instructions. RNA concentration was measured using a spectrophotometer. QuantiTect SYBR Green system (Qiagen, cat no. 204243) was used according to the manufacturers instructions for one step RT-PCR in a total of $15 \mu \mathrm{l}$ reaction volumes, including $0.5 \mu \mathrm{M}$ each primer and $40 \mathrm{ng}$ RNA. Realtime cycler conditions were RT: $50{ }^{\circ} \mathrm{C}$ for $30 \mathrm{~min}$; PCR: initial activation $95^{\circ} \mathrm{C}$ for $15 \mathrm{~min}$ followed by 40 cycles of denaturation $94{ }^{\circ} \mathrm{C}$ for $15 \mathrm{~s}$, annealing $57^{\circ} \mathrm{C}$ for $30 \mathrm{~s}$, extension $72{ }^{\circ} \mathrm{C}$ for $30 \mathrm{~s}$, and a final extension of $72{ }^{\circ} \mathrm{C}$ for $60 \mathrm{~s}$. The following primers were used:

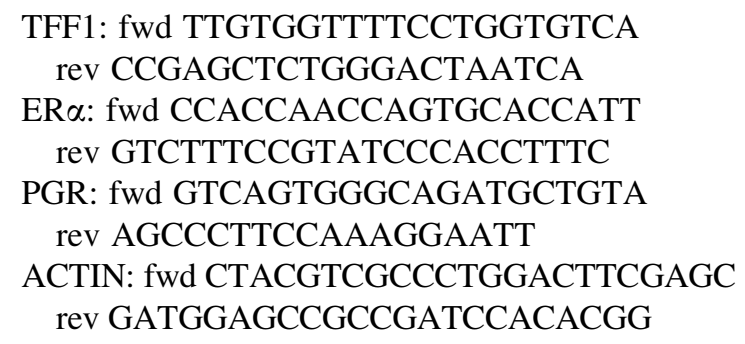

\section{Western analysis}

Cells were washed twice with PBS and lysed in ice-cold lysis buffer (50 mM Tris (pH 7.5), $5 \mathrm{mM}$ EDTA (pH 8.5), $150 \mathrm{mM} \mathrm{NaCl}, 1 \%$ Triton X-100, aprotinin $10 \mu \mathrm{g} / \mathrm{ml}$, and $1 \times$ protease cocktail inhibitor (Roche) for $10 \mathrm{~min}$ and the debris was cleared by centrifugation at 13000 r.p.m. for $6 \mathrm{~min}$ at $4{ }^{\circ} \mathrm{C}$ ). Protein lysates $(100 \mu \mathrm{g})$ were resolved on $7.5-12 \%$ SDS-PAGE and electrophoretically transferred to Immobilon-P membranes. After transfer, membranes were blocked and probed with primary antibody overnight at $4{ }^{\circ} \mathrm{C}$. Immunoreactive bands were detected using chemiluminescent reagents (ECL or SuperLuminol) and photographic paper (Hyperfilm, Amersham). The following antibodies were used: ER $\alpha$ (F-10; Santa Cruz Biotech, Santa Cruz, CA, USA sc8002), PGR (ab-8; Neomarkers, Stratech Scientific Ltd, Newmarket, Suffolk, UK (MS-298)), P-ERK1/2 (1:1000, Cell Signaling, New England Biolabs, Hitchin, Herts, UK \#9101), phospho-Ser ${ }^{118}$ ER $\alpha$ (1:500, Cell Signaling \#2511), phospho-Ser ${ }^{167}$ ER $\alpha$ (1:500, Cell Signaling \#2514), and actin (1:120 000, CP01, Calbiochem, La Jolla, CA, USA). Integrated optical density absorbance values were obtained by densitometric analysis using a gel scanner and analyzed by 'Labworks' gel analysis software (UVP Life Sciences, Cambridge, UK).

\section{Chromatin immunoprecipitation assays (ChIP)}

Cells were grown to $85-90 \%$ confluence in phenol redfree DMEM with 5\% DCC for at least $48 \mathrm{~h}$. Cells were 
cross-linked with $1 \%$ formaldehyde $\left(37^{\circ} \mathrm{C}\right.$ for $\left.10 \mathrm{~min}\right)$ at 10 -min interval over a 90-min time course. Unreacted formaldehyde was quenched by gentle agitation at room temperature for $10 \mathrm{~min}$ with $0.125 \mathrm{M}$ glycine. Cells were then washed twice with ice-cold PBS, collected into PBS containing protease inhibitors (Roche), and centrifuged for $4 \mathrm{~min}$ at 2000 r.p.m. at $4{ }^{\circ} \mathrm{C}$. The pellets were resuspended in lysis buffer (1\% SDS, 10 mM EDTA, $50 \mathrm{mM}$ Tris-HCl $(\mathrm{pH} 8.1)$, and $1 \times$ protease inhibitor cocktail), incubated on ice for $10 \mathrm{~min}$, and sonicated $(12 \times 20 \mathrm{~s}$ at two amplitude microns, Soniprep 150, MSE) to fragment DNA to $\sim 500 \mathrm{bp}$. Following centrifugation for $15 \mathrm{~min}$ at 13000 r.p.m. and $4{ }^{\circ} \mathrm{C}$, supernatants were collected and resuspended in dilution buffer $(0.01 \%$ SDS, $1 \%$ Triton X-100, $1.2 \mathrm{mM}$ EDTA, $16.7 \mathrm{mM}$ Tris- $\mathrm{HCl}(\mathrm{pH} 8.1), 167 \mathrm{mM} \mathrm{NaCl}$, and $1 \times$ protease inhibitor cocktail). Chromatin were precleared with $1 \mu \mathrm{g}$ anti-rabbit or anti-mouse $\mathrm{IgG}, 2 \mu \mathrm{g}$ sheared salmon sperm DNA, and Protein-G-Agarose $(50 \mu \mathrm{l}$ of $50 \%$ slurry in dilution buffer) for $3 \mathrm{~h}$ at $4{ }^{\circ} \mathrm{C}$. Immunoprecipitation using Protein-G-Agarose Beads (Roche) was performed overnight at $4{ }^{\circ} \mathrm{C}$ with antiER $\alpha$ HC-20 antibody (sc-543, Santa Cruz). Beads were washed sequentially for $5 \mathrm{~min}$ each at $4{ }^{\circ} \mathrm{C}$ with TSE I (20 mM Tris (pH 8.1), $2 \mathrm{mM}$ EDTA, $150 \mathrm{mM} \mathrm{NaCl}$, $1 \%$ Triton $\mathrm{X}-100$, and $0.1 \%$ SDS), TSE II (20 mM Tris (pH 8.1), 2 mM EDTA, $500 \mathrm{mM} \mathrm{NaCl}, 1 \%$ Triton $\mathrm{X}-100$, and $0.1 \%$ SDS), and buffer III (10 mM Tris (pH 8.1), $0.25 \mathrm{M} \mathrm{LiCl}, 1 \mathrm{mM}$ EDTA, $1 \% \mathrm{NP} 40$, and $1 \%$ deoxycholate). Precipitates were then washed twice with TE buffer and the protein/DNA complexes were eluted twice with $0.1 \mathrm{M} \mathrm{NaHCO}_{3}$ and $1 \%$ SDS. Heat treatment at $65^{\circ} \mathrm{C}$ overnight reversed formaldehyde cross-links. DNA fragments were purified using QIAquick Spin Kit columns (Qiagen) and amplified using the QuantiTect SYBR Green system (Qiagen, cat no. 204242). TFF1 PCR conditions were: initial activation of $95^{\circ} \mathrm{C}$ for $15 \mathrm{~min}$ followed by 45 cycles of $94{ }^{\circ} \mathrm{C}$ for $15 \mathrm{~s}, 55^{\circ} \mathrm{C}$ for $30 \mathrm{~s}, 72^{\circ} \mathrm{C}$ for $30 \mathrm{~s}$, and a final extension of $72{ }^{\circ} \mathrm{C}$ for $5 \mathrm{~min}$. TFF1 primer sequences: fwd GACGGAATGGGCTTCATGAGC and rev CTGAGACAATAATCTCCACTG. For the distal region, primers were: fwd GAGTTTGGCCTCCCACATTA and rev CTTGCCTCTGCATTCTCTCC.

\section{Short interfering (siRNA) transfections}

MCF-7 cells were seeded at $0.5 \times 10^{6}$ cells per $\mathrm{T} 75$ flask in DMEM as mentioned previously. After $24 \mathrm{~h}$, the media were changed to phenol red-free containing DMEM with 5\% DCC for $48 \mathrm{~h}$. LCC1 and LCC9 cells were seeded directly into phenol red-free containing
DMEM with 5\% DCC for $24 \mathrm{~h}$ prior to transfection. Cells were transfected with siRNA for $4 \mathrm{~h}$ using Oligofectamine reagent (Invitrogen) after which time $1 \mathrm{nM} \mathrm{E}_{2}$ was added for a further $48 \mathrm{~h}$ prior to RNA and protein extraction. For the 7-day time course, the media were left unchanged after the initial changes. For siRNA growth assays, cells were seeded as for growth characterization as mentioned previously. siRNA transfections were carried out as described earlier but scaled down for 24-well plates. Following siRNA treatment for $4 \mathrm{~h}$, cells were treated with $1 \mathrm{nM} \mathrm{E}_{2}$ or $100 \mathrm{nM}$ fulvestrant or a combination and cell counts on days 0,3 , and 6 were estimated using a Coulter counter. The following siRNA sequences were used: ER RNAi 1; ESR1 SMARTpool (four pooled sequences; Upstate Biotechnology, Lake Placed, NY, USA; M-003401; $100 \mathrm{nmol}$ ), ER RNAi 2; 5'-AAACAGGAGGAAGAGCTGCCA (Ambion; $40 \mathrm{nmol}$ ), ER RNAi 3; 5'AACCTCGGGCTGTGCTCTTTT (Ambion, Huntingdon, Cambridgeshire, UK; $40 \mathrm{nmol}$ ), and negative RNAi: Upstate (D-001206; $100 \mathrm{nmol}$ ).

\section{Results}

\section{Increased ER $\alpha$ expression in resistant cell lines}

To explore the possibility that high ER $\alpha$ expression leads to estrogen-independent growth in endocrineresistant cells, the expression levels of ER $\alpha$ in resistant lines (LCC1 and LCC9) were compared with levels in wild-type MCF-7 cells. Both resistant lines expressed between four- and elevenfold more ER $\alpha$ mRNA than wild-type cells (Fig. 1A). ER $\alpha$ protein levels were clearly elevated in LCC 1 cells relative to MCF-7 cells (sevenfold) and less markedly in LCC9 cells (Fig. 1B). $\mathrm{E}_{2}$ decreased ER $\alpha$ protein in MCF-7 cells at $48 \mathrm{~h}$ and this has been explained by proteosomal degradation, a process speculated to limit the action of estrogen signaling (Nawaz et al. 1999; Fig. 1C). Similarly, both resistant lines demonstrated ER $\alpha$ turnover, suggesting that $\mathrm{ER} \alpha$ is binding to $\mathrm{E}_{2}$ in all cases. In contrast, tamoxifen treatment results in maintenance of the receptor expression levels in all three cell lines (Fig. 1C).

Addition of $1 \mathrm{nM} 17 \beta$-estradiol ( $\left.\mathrm{E}_{2}\right)$ to MCF-7 cells produced a marked stimulation of growth to cells cultured in estrogen-depleted (double charcoalstripped FCS) medium (Fig. 2A). In the absence of $\mathrm{E}_{2}, \mathrm{MCF}-7$ cells are essentially static (Fig. 2A). In contrast, LCC1 cells grow rapidly in estrogen-depleted conditions and show an approximately twofold stimulation of growth on addition of $\mathrm{E}_{2}$ (Fig. 2B). LCC9 cells showed a lack of response to $\mathrm{E}_{2}$, again 

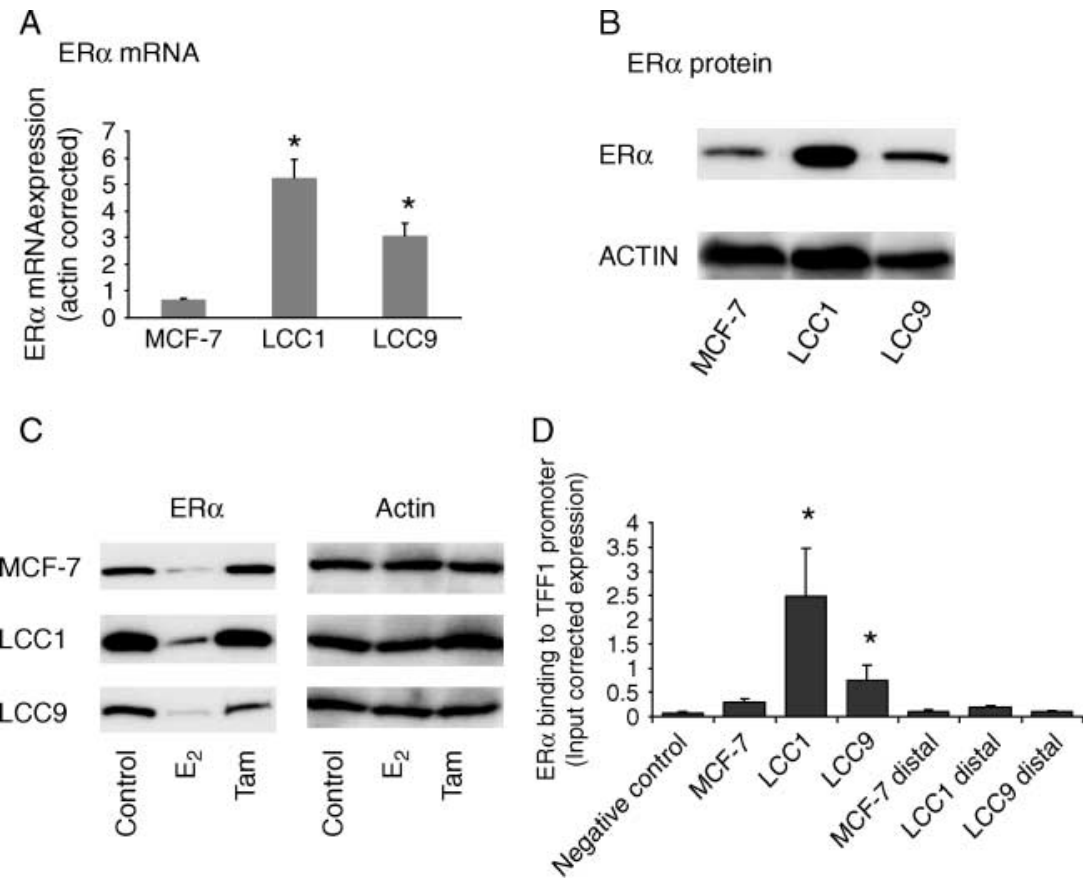

Figure 1 ER $\alpha$ expression in MCF-7, LCC1, and LCC9 cells. (A) ER $\alpha$ mRNA expression. Cells were grown in charcoal-stripped serum-containing medium for at least $48 \mathrm{~h}$ and RNA was collected. A representative experiment is shown of at least two experiments carried out. Each column presents mean of triplicate RT-PCR analysis for each sample demonstrating mRNA expression relative to actin expression. Error bars = S.D. Statistical significance noted for treatment groups versus matched control (one-way ANOVA and multiple comparison Tukey-Kramer test; $\left.{ }^{\star} P<0.05\right)$. (B) Western blot analysis of ER $\alpha(66 \mathrm{kDa})$ in breast cancer cell lines grown in charcoal-stripped serum-containing medium for $48 \mathrm{~h}$ prior to protein collection. One hundred micrograms of protein were loaded per lane and detected using either anti-ER $\alpha$ (Santa Cruz Biotech) or anti-actin (Calbiochem) antibodies as described in Materials and methods. (C) Western blot analysis of $\mathrm{ER} \alpha(66 \mathrm{kDa})$ in breast cancer cell lines grown in charcoal-stripped serum-containing medium for at least $48 \mathrm{~h}$ prior to protein collection. One hundred micrograms of protein were loaded per lane and detected using either anti$\mathrm{ER} \alpha$ (Santa Cruz Biotech) or anti-actin (Calbiochem) antibodies as described in Materials and methods. (D) ER $\alpha$ binding to the TFF1 promoter. Basal recruitment of ER $\alpha$ to the TFF1 promoter was determined by ChIP analysis on untreated cells. The ChIP method used was as described in Materials and methods and immunoprecipitated TFF1 promoter was quantified by real-time PCR. The input-corrected expression values were determined by normalizing to the inputs. Data are presented as mean + S.E. Groups were compared with the Kruskal-Wallis test with Dunn's multiple comparison test $\left({ }^{*} P<0.05\right)$. Binding to the promoter region is compared with binding to a region $3.5 \mathrm{~kb}$ distal to the promoter wherein only background binding was observed.

growing very rapidly in the absence of $\mathrm{E}_{2}$ (Fig. 2C). Addition of $1 \mu \mathrm{M}$ tamoxifen to MCF-7 cells antagonized the $\mathrm{E}_{2}$-stimulated growth in this cell line. Tamoxifen also inhibited the $\mathrm{E}_{2}$-stimulated growth of LCC1 cells but had no effect on LCC9 cells (Fig. 2B and $\mathrm{C}$ ). These results are consistent with wild-type cells being estrogen dependent, LCC 1 cells demonstrating partial estrogen dependence and LCC9 cells being fully estrogen independent.

\section{Reduced ER $\alpha$ Ser $^{118}$ phosphorylation in LCC9 cells}

Several frequently cited mechanisms of estrogenindependent activation of $\mathrm{ER} \alpha$ involve phosphorylation of $\mathrm{ER} \alpha$ at the $\mathrm{Ser}^{118}$ or $\mathrm{Ser}^{167}$ residues mediated via ERK or Akt respectively (Bunone et al. 1996, Martin et al. 2000, Lannigan 2003). While the Ser ${ }^{118}$ residue is a major site of $\mathrm{E}_{2}$-induced phosphorylation, $\operatorname{Ser}^{167}$ is not (Lannigan 2003). The latter site is activated by growth factor signaling. In view of these previous observations, we first investigated whether $\mathrm{ER} \alpha \operatorname{Ser}^{118}$ or $\mathrm{Ser}^{167}$ phosphorylation were increased in the absence of estrogen in the resistant cell lines. Neither was there evidence of increased Ser $^{118}$ phosphorylation in the resistant lines relative to MCF-7 under basal conditions, nor was Ser ${ }^{167}$ phosphorylation increased (Fig. 3A-C). Furthermore, phospho-ERK1/2 expression was unchanged in the lines (Fig. 3C). On $\mathrm{E}_{2}$ addition, there was a marked increase in $\mathrm{Ser}^{118}$ phosphorylation in MCF-7 cells and this was also observed in the LCC1 cell line (Fig. 3A and $\mathrm{B})$. However, minimal change was observed on $\mathrm{E}_{2}$ addition to LCC9 cells (Fig. 3A and B). Ser ${ }^{118}$ phosphorylation has been proposed to affect cofactor recruitment and this might explain the reduced 

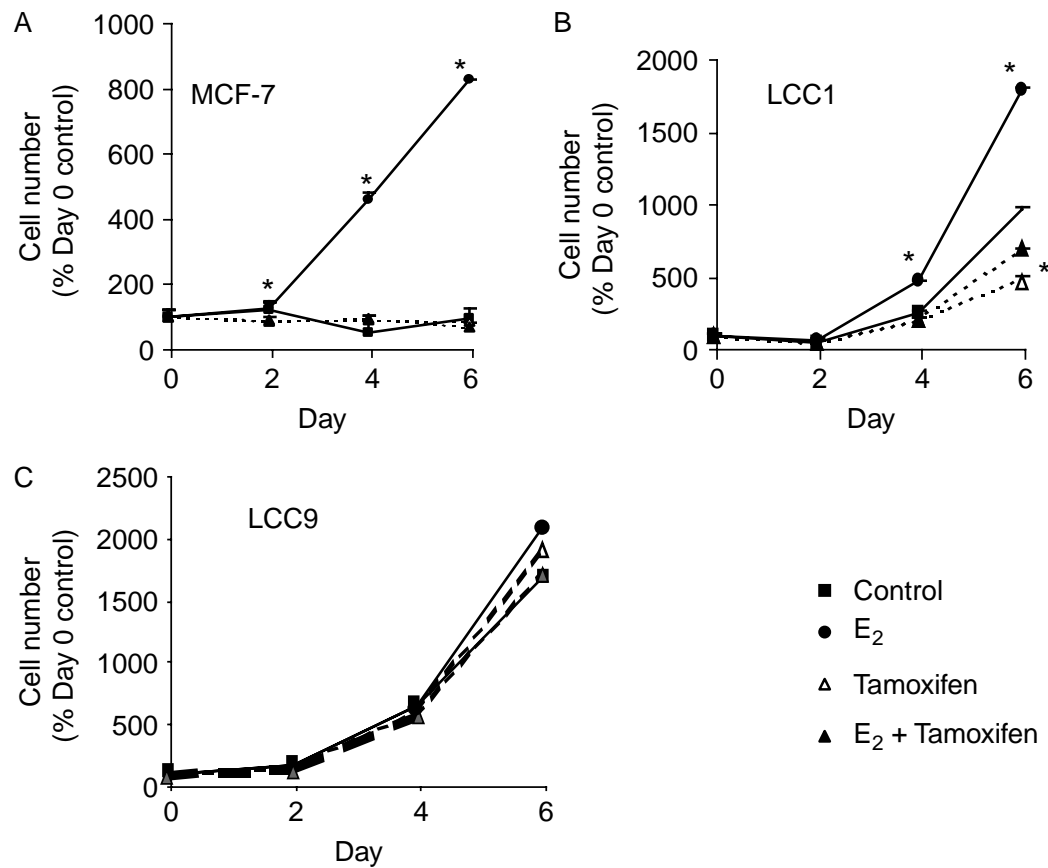

- Control

- $\mathrm{E}_{2}$

$\Delta$ Tamoxifen

$\Delta \mathrm{E}_{2}+$ Tamoxifen

Figure 2 Growth characterization of MCF-7 and MCF-7 variant cells. (A) MCF-7 cells, (B) LCC1, and (C) LCC9 cells were plated for $24 \mathrm{~h}$ and maintained in reduced media for $48 \mathrm{~h}$ before treatment. Cells were then left untreated (control group), treated with $1 \mathrm{nM} \mathrm{E}_{2}$, $1 \mu \mathrm{M}$ tamoxifen or $1 \mathrm{nM} \mathrm{E}_{2}$ and $1 \mu \mathrm{M}$ tamoxifen. Cells were counted on day 0 ( $72 \mathrm{~h}$ after plating/day of treatment start) and days $2 / 4 / 6$ using a Coulter counter. Mean cell counts of triplicate samples and duplicate counts for each time point in each treatment group are expressed. Error bars=S.D. A representative experiment is shown of at least four experiments carried out.

transcriptional (as mentioned below) and growth responses observed on $\mathrm{E}_{2}$ addition to this cell line. Tamoxifen alone produced a small increase in $\operatorname{Ser}^{118}$ phosphorylation in MCF-7 and LCC1 cells but not in LCC9 cells (Fig. 3A and B). Tamoxifen also produced a reduction of estrogen's $\operatorname{Ser}^{118}$ phosphorylation in the MCF-7 and LCC1 cell lines (Fig. 3A and B).

\section{Modified DNA binding of ER $\alpha$ in resistant cell lines}

To explore whether high ER $\alpha$ expression was reflected in enhanced DNA binding in the absence of $\mathrm{E}_{2}$, ChIP methodology was used to examine ER $\alpha$ binding to the promoter of the $\mathrm{E}_{2}$-responsive gene TFF1 in the MCF-7, LCC1, and LCC9 cell lines. LCC9 cells had $>2.5$-fold greater ER $\alpha$ binding to the TFF1 promoter than MCF-7 cells (Fig. 1D). However, this binding was significantly higher in LCC1 cells with levels greater than eightfold above MCF-7 cells. This enhanced ER $\alpha$ binding in LCC1 cells was equivalent to the increased expression of ER $\alpha$ protein and is consistent with the suggestion by Fowler $e t$ al. (2004) that enhanced ER $\alpha$ protein expression can lead to increased DNA binding. As a control, binding to a region $3.5 \mathrm{~kb}$ distal to this region indicated only background levels as expected (Fig. 1D).

\section{Growth responses to estrogen and tamoxifen in the wild-type and variant cell lines are reflected in transcriptional changes}

To investigate the differences in estrogen and antiestrogen activation processes, indicator genes that reflected the different growth responses were next investigated. Transcriptional changes in the estrogenregulated genes TFF1 and PGR were measured and modulated expression was compared with the growth changes.

Expression of TFF1 mRNA in the absence of $E_{2}$ was higher in both resistant lines compared with MCF-7 cells (Fig. 4A). After 48-h $\mathrm{E}_{2}(1 \mathrm{nM})$ treatment, TFF1 mRNA was increased by $>20$-fold in MCF-7 cells, but only oneto twofold in the resistant lines although this increase was significant. Tamoxifen $(1 \mu \mathrm{M})$ produced a small increase in TFF1 expression in MCF-7 and LCC1 cells but not in the LCC9 cell line (Fig. 4A). These levels broadly reflect the growth differences observed.

The expression of PGR mRNA in the absence of $E_{2}$ was greater in LCC1 and LCC9 lines compared with MCF-7 cells (Fig. 4B). As for TFF1, after 48-h $\mathrm{E}_{2}$ treatment, PGR mRNA was increased by $>20$-fold in MCF-7 cells and 2-5-fold in LCC1 and LCC9 cell lines (Fig. 4B). Tamoxifen also increased the PGR mRNA 


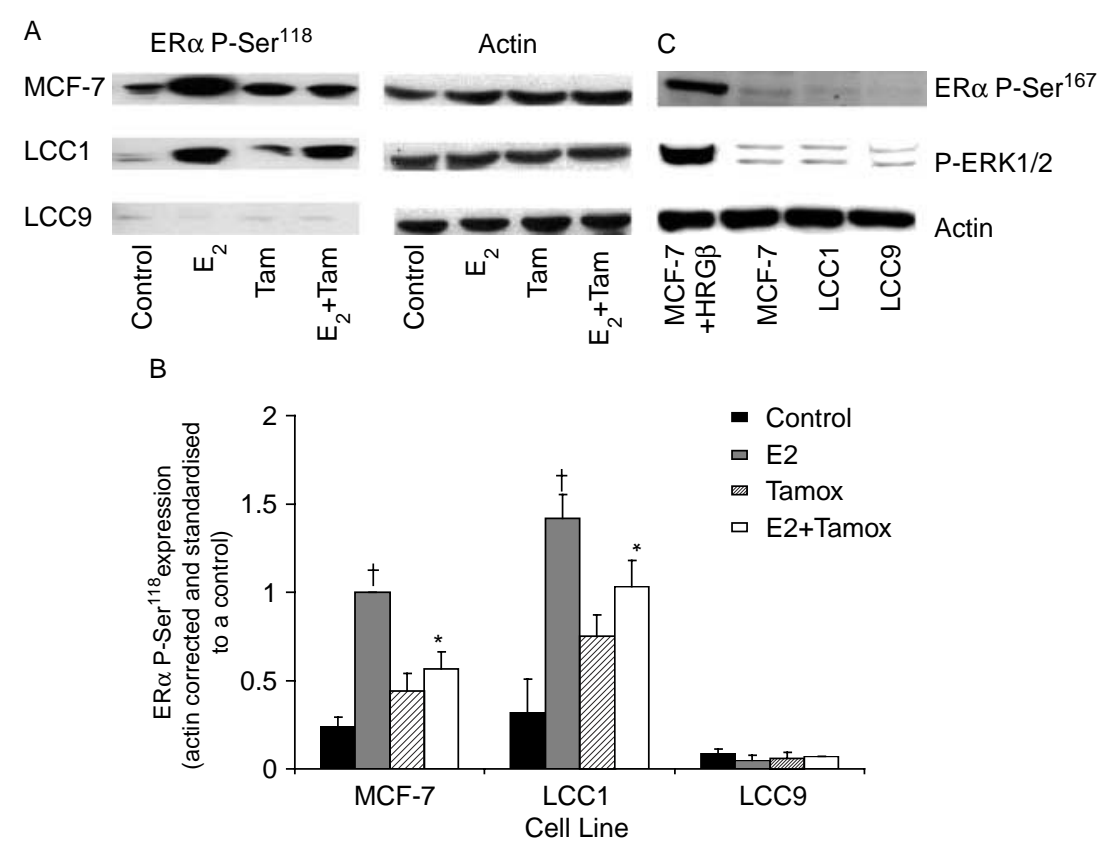

Figure 3 Effects of $E_{2}$ and tamoxifen on $E R \alpha$ phosphorylation in the resistant cell lines. (A) Western analysis of ER $\alpha$ phospho-Ser ${ }^{118}$ after 30-min treatment with control (no treatment), $1 \mathrm{nM} \mathrm{E}_{2}, 1 \mu \mathrm{M}$ tamoxifen, or $1 \mathrm{nM} \mathrm{E}_{2}$ and $1 \mu \mathrm{M}$ tamoxifen. Lysates were run on a $10 \%$ SDS gel and membranes probed with anti-phospho ER $\alpha \operatorname{Ser}^{118}$ antibody (1:1000). Lysates were also probed for actin expression to compare protein loading. (B) Histogram representing optical densities from triplicate western blots of ER $\alpha$ phosphoSer $^{118}$ after 30 -min treatment with control (no treatment), $1 \mathrm{nM} \mathrm{E}_{2}, 1 \mu \mathrm{M}$ tamoxifen, or $1 \mathrm{nM} \mathrm{E}_{2}$ and $1 \mu \mathrm{M}$ tamoxifen. Values were actin corrected and then standardized to a control sample. The control sample was a $30 \mathrm{~min} \mathrm{E}_{2}$-treated MCF-7 sample and was used on all gels as a standard to allow comparisons between runs. Statistical comparisons were made with each cell line's control level; ${ }^{\star} P<0.01 ;{ }^{\dagger} P<0.001$ (ANOVA). (C) Western analysis of ER $\alpha$ phospho-Ser ${ }^{167}$ and phospho-ERK1/2 in cell lines. Untreated lysates were probed with antibodies specific for ER $\alpha$ phospho-Ser ${ }^{167}$ and phospho-ERK1/2. A positive control lane of MCF-7 cells treated with $1 \mathrm{nM} \mathrm{HRG} \beta$ was used. Lysates were also probed for actin expression.

expression level not only in MCF-7 cells, but also in $\mathrm{LCC} 1$ cells producing effects equivalent to that of $\mathrm{E}_{2}$ in the latter cell line. No change was observed in the LCC9 cell line.

These results are consistent with transcription of TFF1 and PGR being increased by ligand-independent mechanisms in LCC1 and LCC9 cell lines with estrogen and tamoxifen producing an additional ligand-dependent increase.

\section{Effect of removal of ER $\alpha$ on the growth of the cell lines}

To determine the relative importance of $\mathrm{ER} \alpha$ on downstream gene expression and growth of MCF-7, LCC1, and LCC9 cells, we investigated the effects of removing ER $\alpha$, either by specific siRNA inhibition of receptor synthesis or through inhibition and degradation of the receptor by fulvestrant.

A panel of interfering RNAs (siRNAs) were initially compared for their ability to transiently reduce ER $\alpha$ expression and were transfected into the MCF-7 cell line. RNAi 1 is a pooled set of four targeted sequences (Imai et al. 2005) while RNAi 2 (5'-AAACAGGAGGAAGAGCTGCCA) and RNAi 3 (5'-AACCTCGGGCTGTGCTCTTTT) are individually targeted sequences (Leu et al. 2004). Of the three, RNAi 2 produced the best reduction of ER $\alpha$ mRNA and protein and was selected for further experiments (Fig. 5A and B). Quantitative RT-PCR analysis showed that, $48 \mathrm{~h}$ after transfection, ER $\alpha$ RNAi 2 treatment resulted in an $85 \%$ decrease in ER $\alpha$ mRNA expression and an $87 \%$ decrease in the presence of $E_{2}$ (Fig. 5C). LCC1 and LCC9 cells have significantly higher basal expression of ER $\alpha$ mRNA and siRNA removal caused an 82 and $73 \%$ decrease respectively with similar reductions in the presence of $\mathrm{E}_{2}$ (Fig. 5C). Western analysis of the MCF-7 and LCC1 cell lines demonstrated that RNAi 2 produced ER $\alpha$ protein knockdown over a 7-day period (Fig. 5D) and it was effective in all three cell lines (Fig. 5E). This reduction in $\mathrm{ER} \alpha$ protein was accompanied by a decrease in PGR protein (Fig. 5E). Thus, it appeared that gene expression in all three cell lines was $\mathrm{ER} \alpha$ dependent. 

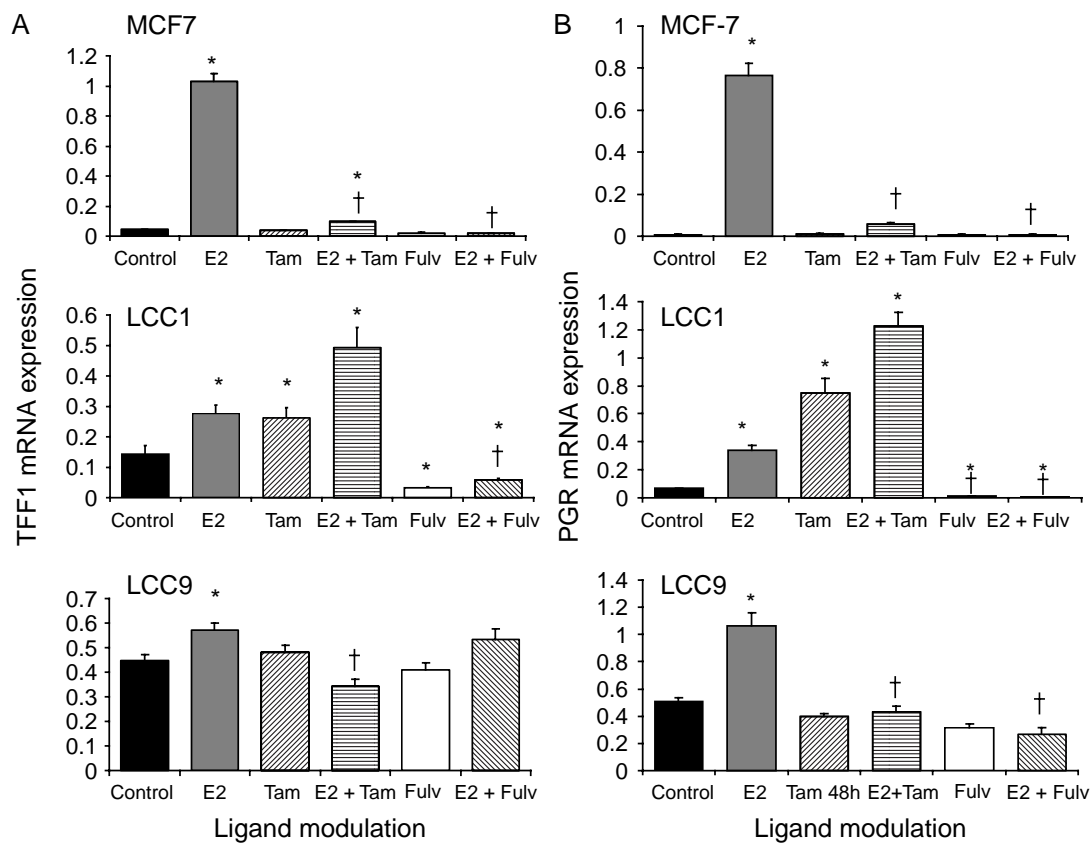

Figure 4 Effect of estrogen, tamoxifen, and fulvestrant on (A) TFF1 expression and (B) PGR mRNA expression in the cell lines. Relative mRNA expression values of TFF1 and PGR in the cell lines were measured by real-time RT-PCR using specific primer pairs. RNA was collected at $48 \mathrm{~h}$ and was extracted from either untreated (control) cells or cells treated with $1 \mathrm{nM} \mathrm{E}_{2}, 1 \mu \mathrm{M}$ tamoxifen, $1 \mathrm{nM} \mathrm{E}_{2}+1 \mu \mathrm{M}$ tamoxifen, $100 \mathrm{nM}$ fulvestrant, or $1 \mathrm{nM} \mathrm{E}_{2}+100 \mathrm{nM}$ fulvestrant. Each column represents mean of triplicate PCR analysis for each sample demonstrating mRNA expression relative to actin expression. Error bars =S.D. Statistical significance noted for treatment groups compared to matched control where ${ }^{\star} P<0.05$, untreated control versus treatment group; ${ }^{\dagger} P<0.05, \mathrm{E}_{2}$ control versus treatment group (ANOVA and multiple Tukey-Kramer comparison test).

This was investigated further using fulvestrant. Fulvestrant abrogates $\mathrm{E}_{2}$-induced gene transcription by binding, blocking, and causing the degradation of $\mathrm{ER} \alpha$ (Parker 1993). Fulvestrant treatment in MCF-7 cells blocked $\mathrm{E}_{2}$-induced expression of TFF1 and PGR (Fig. 4A and B). In addition, ligand-independent and $\mathrm{E}_{2}$-induced TFF1 and PGR expression in LCC1 cells were reduced on fulvestrant treatment. These data confirm that for LCC1 cells TFF1 and PGR induction are dependent on ER $\alpha$ expression. However, LCC9 cells are resistant to fulvestrant treatment and as such no change in TFF1 expression and only a minor change in PGR expression was observed. The effect of fulvestrant on the growth of all three cell lines was also investigated in the complete absence of serum (Fig. 6). Under these conditions, MCF-7 cells did not grow over a $72-\mathrm{h}$ period. LCC1 cells, however, still proliferated and the addition of $\mathrm{E}_{2}$ had little effect on growth confirming their independence of $E_{2}$. Under these conditions, fulvestrant was able to oppose the effect of low concentrations of $\mathrm{E}_{2}$ again indicating dependence on ER $\alpha$. In contrast, LCC9 cells were completely insensitive to both $\mathrm{E}_{2}$ and fulvestrant. Fulvestrant degraded ER $\alpha$ protein in all three lines which is shown in Fig. 7A.

To determine how critical levels of ER $\alpha$ expression were for the growth of MCF-7, LCC1, and LCC9 cell lines, we used RNAi removal with or without fulvestrant to inhibit the synthesis of $\mathrm{ER} \alpha$ protein (Fig. 7B-D). $\mathrm{E}_{2}$ induced MCF-7 cell growth was significantly decreased (33\%) by $\mathrm{ER} \alpha$ removal and abolished by all combinations of fulvestrant alone or with RNAi. LCC1 cells grew in the absence of $\mathrm{E}_{2}$ and RNAi removal had only a minor effect on growth. $\mathrm{E}_{2}$-induced LCC1 cell growth was reduced by approximately $40 \%$ when ER $\alpha$ was removed through RNAi, but, unlike MCF-7 cells, fulvestrant alone was not enough to abolish growth this, however, could be accomplished though through combination with RNAi. LCC9 cell growth in the absence of $E_{2}$ was reduced by $E R \alpha$ RNAi. A similar decrease was observed in the presence of $E_{2}$. LCC9 cells are fulvestrant resistant and no effect on growth was observed with this agent. No combinations of fulvestrant or RNAi were able to totally abolish growth. These results indicate a varying degree of dependence on $\mathrm{ER} \alpha$ for growth in the three cell lines. 
A

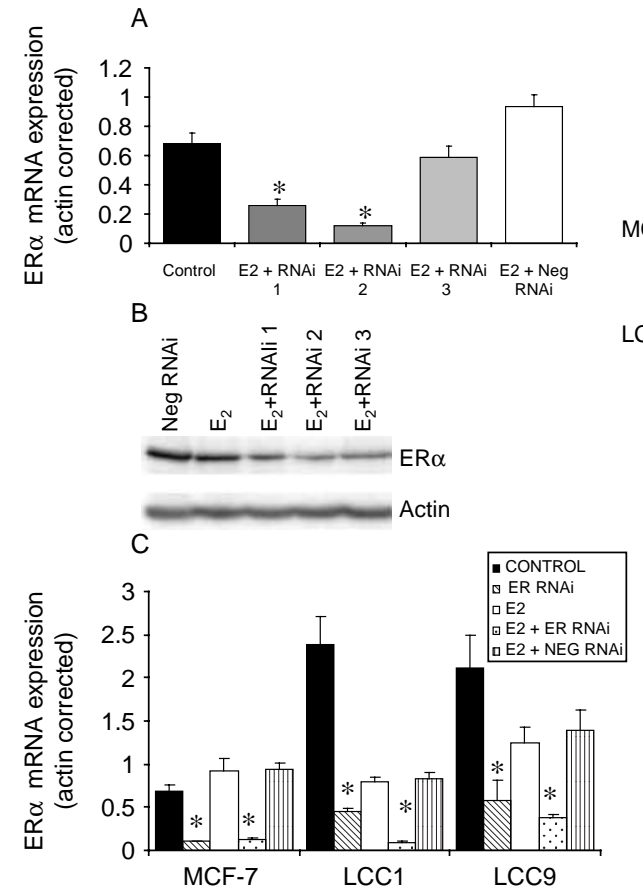

$\mathrm{D}$

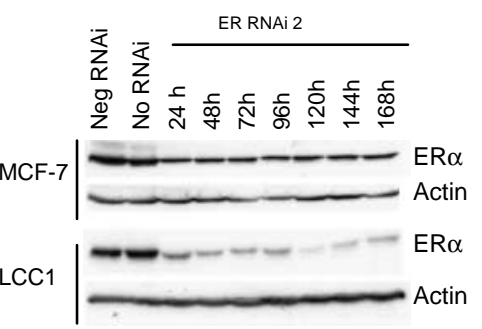

$E$

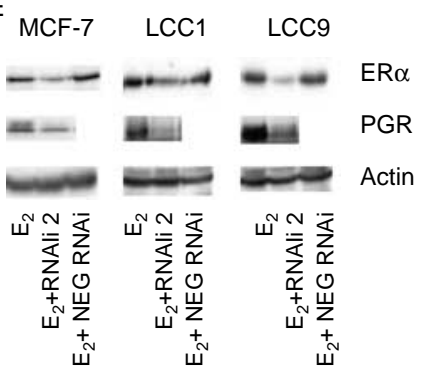

Figure 5 Effects of ER $\alpha$ RNAi on ER $\alpha$ and PGR expression in the cell lines. (A) Expression of ER $\alpha$ mRNA after treatment with a range of ER $\propto$ mRNA-targeted RNAis. ER $\alpha$ mRNA expression was measured by quantitative RT-PCR of mRNA from MCF-7 cells $48 \mathrm{~h}$ after RNAi treatment in the presence of $1 \mathrm{nM} \mathrm{E}_{2}$. Data are presented as mean \pm S.D. of actin-corrected values from triplicate samples. The RNAi transfection method and RNAi sequences used are described in Materials and methods. Statistical significance noted for treatment groups compared with matched control where ${ }^{*} P<0.05$, untreated control versus treatment group (ANOVA and multiple Tukey-Kramer comparison test). (B) Western analysis of ER $\alpha$ protein expression in MCF-7 cells $48 \mathrm{~h}$ after siRNA treatment. ER $\alpha$ was probed with the F-10 antibody and actin is shown as a loading control. (C) Expression of ER $\alpha$ mRNA after treatment with RNAi 2. ER $\alpha$ mRNA expression was measured by quantitative RT-PCR of mRNA from cell lines $48 \mathrm{~h}$ after RNAi 2 treatment in the presence or absence of $1 \mathrm{nM} \mathrm{E}_{2}$. Data are presented as mean \pm s.D. of actin-corrected values from triplicate samples. The RNAi transfection method and RNAi sequences used are described in Materials and Methods. Statistically significance differences are noted for treatment groups compared with matched control where ${ }^{*} P<0.05$, untreated control versus treatment group (ANOVA and multiple Tukey-Kramer comparison test). (D) Western analysis time course of the effect of RNAi 2 treatment on ER $\alpha$ protein expression in the MCF-7 and LCC1 cell lines. ER $\alpha$ was probed with the F-10 antibody and actin is shown as a loading control. (E) Western analysis of ER $\alpha$ and PGR protein expression in the cell lines $48 \mathrm{~h}$ after siRNA treatment. ER $\alpha$ was probed with the F-10 antibody, PGR with Ab 8 and actin is shown as a loading control.

\section{Discussion}

Aromatase inhibitors are now used for the adjuvant treatment of most hormone receptor-positive early breast cancer. Despite the improvement they offer over tamoxifen alone, recurrences still occur, and thus models of resistance to both tamoxifen and estrogen deprivation are required. The series of MCF-7-derived cell lines provides an excellent model system for the exploration of mechanisms of stepwise acquisition of resistance to tamoxifen and estrogen deprivation. Most models to date have been derived in vitro, which makes LCC1 cells interesting as the initial estrogen deprivation was achieved in vivo and therefore might reflect features that could arise in a primary breast cancer (Brunner et al. 1993). In many of the in vitro-derived LTED models, acquired resistance is due to enhanced sensitization to low concentrations of estrogen, which often involves crosstalk with growth factor-signaling pathways (Martin et al. 2003, 2005a,b). LCC1 cells have certain of the characteristics of the LTED phenotype (Yue et al. 2002, Martin et al. 2003, $2005 a, b$, Santen et al. 2005) such as a higher expression level of $\mathrm{ER} \alpha$, an ability to grow in lowestrogen conditions and elevated TFF1 expression. The continuous culturing of LCC1 cells in low estrogen conditions may well contribute to the increased expression of $\mathrm{ER} \alpha$ in this cell line.

However, unlike most LTED-derived cells, which show little response to physiological levels of estrogen yet are sensitive to very low levels of estrogen, LCC1 cells appear truly insensitive to the addition of low levels of exogenous estrogen. Similarly, while most LTED cells show basal activation of ERK1/2 activation and $\mathrm{ER} \alpha$ via $\operatorname{Ser}^{118}$ phosphorylation, $\mathrm{LCC} 1$ and 

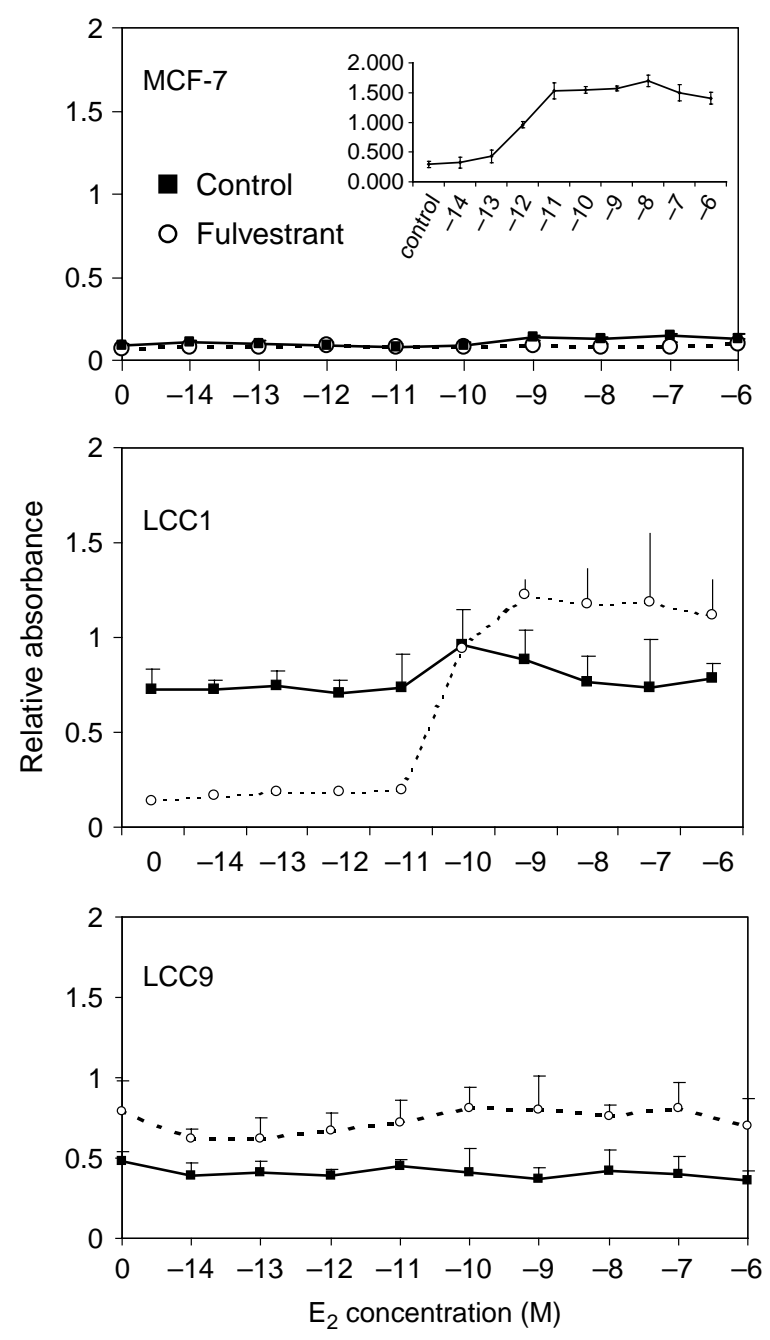

Figure 6 Effect of the growth of the cell lines in serum-free media and treated with varying concentrations of $E_{2}$ in the absence or presence of fulvestrant $(1 \mathrm{nM})$. Cells were plated and after establishment placed in serum-free medium for $48 \mathrm{~h}$. $E_{2}$ with or without fulvestrant was added and plates left for $72 \mathrm{~h}$. Relative cell numbers were then assessed by SRB assay as described in Materials and methods. Inset in MCF-7 figure: effect of $E_{2}$ on MCF-7 cells grown in $5 \%$ double charcoalstripped fetal serum.

LCC9 cells do not. The ER, however, is still clearly functional in LCC1 cells and linked to growth regulation as estrogen addition can produce an increase in growth which could be reversed by tamoxifen. ER $\alpha$ is also downregulated by the addition of estrogen and markedly phosphorylated at $\operatorname{Ser}^{118}$. Additionally, the $\mathrm{ER} \alpha$ downregulator fulvestrant reduces expression of TFF1 and inhibits growth. These effects are more marked when cells are exposed to fulvestrant with siRNA removal of ER $\alpha$.

While constitutive activation of ER $\alpha$ may be achieved in some instances by phosphorylation of
$\operatorname{Ser}^{118}$ mediated by growth factor-driven activation of ERK, an increased expression of ER $\alpha$ alone might account for increased DNA binding. In support of this, there was enhanced binding of ER $\alpha$ to the TFF1 promoter in the absence of added estrogen in both the LCC1 and LCC9 cell lines. In addition, TFF1 transcription was markedly increased in the resistant cell lines consistent with this enhanced ER $\alpha$-binding driving transcription. Direct support for such a mechanism has recently been demonstrated in an MCF-7 cell line using a tetracycline-inducible ER $\alpha$ overexpression model (Fowler et al. 2004, 2006). As with the data mentioned earlier, the results suggested that elevated levels of ER $\alpha$ resulted in activation of receptor transcriptional function in a manner distinct from mechanisms that involve ligand binding or growth factor-induced phosphorylation of the $\mathrm{Ser}^{104}$, $\mathrm{Ser}^{106}$ or $\mathrm{Ser}^{118}$ sites. The mechanism required the amino-terminal A/B domain and was not inhibited by tamoxifen. It was also uncoupled from ERK activation. The hypothesis proposed was that overexpression of unliganded $\mathrm{ER} \alpha$ stabilized interactions with the basal transcriptional machinery, which at normal receptor levels may be too weak to support effective transcription (Fowler et al. 2004).

These results together support a model wherein growth (and TFF1 transcriptional activation) in LCC1 cells is dependent on ER $\alpha$. This dependency has some ligand (i.e., estrogen) responsiveness but is largely ligand independent. The ligand-dependent component may be reversed by tamoxifen. The ligand independency appears to involve neither growth factor activation via the $\operatorname{Ser}^{118}$ or $\operatorname{Ser}^{167}$ phosphorylation routes nor hypersensitization (where low levels of estrogen produce apparent independence). Instead the ligand independence appears to be explained by the high level of ER expression leading to constitutive activation and promoting DNA binding and transcriptional activation.

We have shown that $\mathrm{ER} \alpha$ is functionally active in the LCC1 model and since this has also been shown in models demonstrating LTED, a logical clinical strategy to attempt after development of resistance in a low estrogen environment (such as produced by aromatase inhibitor treatment) is to downregulate the receptor using fulvestrant (Johnston et al. 2005, Martin et al. 2005a,b). This strategy clearly is effective at inhibiting growth in LCC1 cells. However, the LCC9 variant was derived after exposure and development of resistance to fulvestrant (Brunner et al. 1997) and showed no growth response to either estrogen or tamoxifen. In this cell line, the negligible changes of 

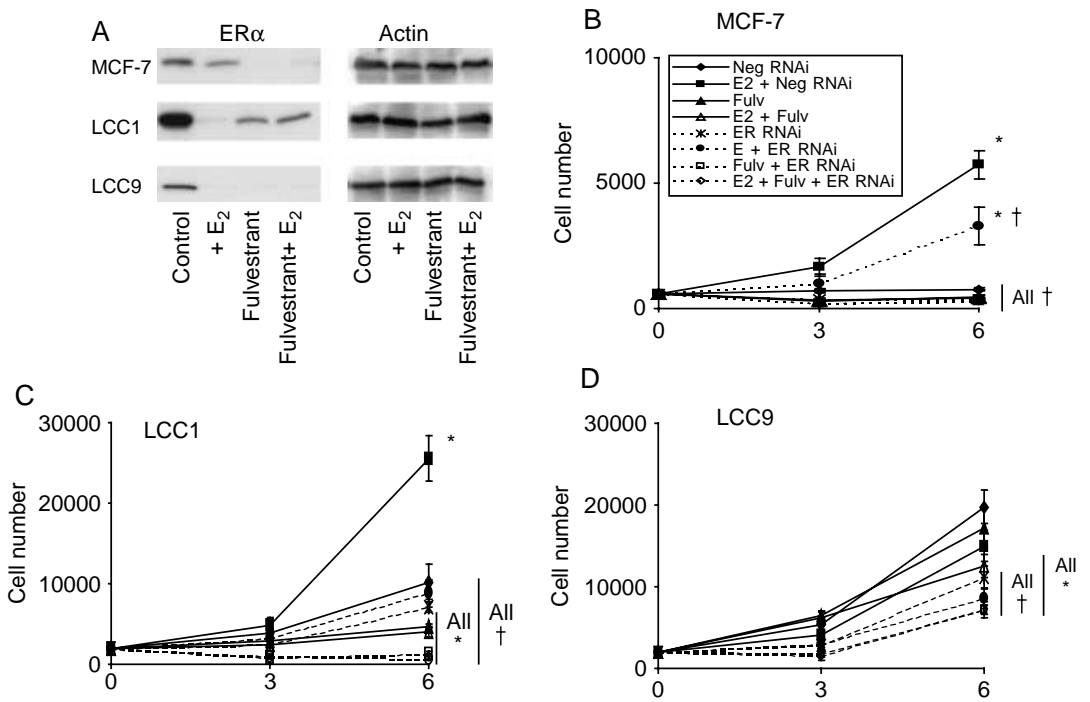

Figure 7 Effect of fulvestrant on ER $\alpha$ expression and combined with ER $\alpha$ siRNA on the growth of the cell lines. (A) Western blot analysis of $\mathrm{ER} \alpha(66 \mathrm{kDa})$ in breast cancer cell lines in control, $1 \mathrm{nM} \mathrm{E} \mathrm{E}_{2}, 100 \mathrm{nM}$ fulvestrant, or $1 \mathrm{nM} \mathrm{E}_{2}$ and $100 \mathrm{nM}$ fulvestranttreated groups at $48 \mathrm{~h}$. One hundred micrograms of protein were loaded per lane and detected using anti-ER $\alpha$ (Santa Cruz Biotech) antibody as described in Materials and Methods. Actin expression is also shown. (B-D) Effects of fulvestrant, ER $\alpha$ siRNA, or combinations on the growth of the cell lines. (B) MCF-7, (C) LCC1, and (D) LCC9 cells were treated with $1 \mathrm{nM} \mathrm{E}, 100 \mathrm{nM}$ fulvestrant, $40 \mathrm{nM} E R \propto$ siRNA, or combinations of these. siRNA treatment was for $4 \mathrm{~h}$ only, while $\mathrm{E}_{2}$ and fulvestrant were present throughout the time course. Comparisons are made with the negative siRNA control which gave an equivalent growth effect to no treatment. Data are presented as mean + S.E. from quadruplicate samples. Statistical significance noted for treatment groups compared with matched control where ${ }^{*} P<0.05$, negative RNAi control versus treatment group; ${ }^{\dagger} P<0.05$, negative RNAi+ $\mathrm{E}_{2}$ control versus treatment group (ANOVA and multiple Tukey-Kramer comparison test).

ER $\alpha \operatorname{Ser}^{118}$ phosphorylation obtained on estrogen or tamoxifen addition contrasted with observations in the other cell lines. Markedly reduced phosphorylation is likely to affect cofactor binding and our initial findings suggest that p160 binding (specifically AIB1) is reduced in this cell line, again consistent with endocrine insensitivity (Kuske et al. 2004). However, it is quite clear that fulvestrant can downregulate the receptor and even extremely high levels of fulvestrant $(10 \mu \mathrm{M})$ were unable to influence growth (data not shown). Despite this, siRNA removal of ER $\alpha$ produced some growth inhibition suggesting a reduced but still measurable dependency on ER $\alpha$.

In conclusion, these results suggest that multiple changes contribute to endocrine resistance. While ER still demonstrates functionality in LCC1 cells, there is a major shift to ligand independence. This independence can be explained by the high level of ER expression found in these cells and could lead to constitutive activation of the receptor. These cells still show a degree of dependency on estrogen and this can be blocked by tamoxifen. Further changes were produced by exposure and development of resistance to fulvestrant including a loss of ER $\alpha \operatorname{Ser}^{118}$ activation, which could account for its loss of sensitivity to estrogen. These data support the view that in the early stages of resistance, SERDs may provide a useful therapeutic option, but other approaches will be required when resistance has developed to these agents.

\section{Acknowledgements}

The authors gratefully acknowledge support from Cancer Research UK for this study. The authors declare that there is no conflict of interest that would prejudice the impartiality of this scientific work.

\section{References}

Ali S \& Coombes RC 2002 Endocrine-responsive breast cancer and strategies for combating resistance. Nature Reviews of Cancer 2 101-112.

Black R, Prescott R, Bers K, Hawkins A, Stewart H \& Forrest P 1983 Tumour cellularity, oestrogen receptors and prognosis in breast cancer. Clinical Oncology 9 311-318.

Brunner N, Boulay V, Fojo A, Freter CE, Lippman ME \& Clarke R 1993 Acquisition of hormone-independent growth in MCF-7 cells is accompanied by increased expression of estrogen-regulated genes but without detectable DNA amplifications. Cancer Research $\mathbf{5 3}$ 283-290. 
Brunner N, Boysen B, Jirus S, Skaar TC, Holst-Hansen C, Lippman J, Frandsen T, Spang-Thomsen M, Fuqua S \& Clarke R 1997 MCF7/LCC9: an antiestrogen-resistant variant in which acquired resistance to the steroidal antiestrogen ICI 182780 confers an early cross-resistance to the nonsteroidal antiestrogen tamoxifen. Cancer Research 57 3486-3493.

Bunone G, Briand PA, Miksicek RJ \& Picard D 1996 Activation of the unliganded estrogen receptor by EGF involves the MAP kinase pathway and direct phosphorylation. EMBO Journal 15 2174-2183.

Clarke R, Liu MC, Bouker KB, Gu Z, Lee RY, Zhu Y, Skaar TC, Gomez B, O'Brien K \& Wang Y 2001 Cellular and molecular pharmacology of antiestrogen action and resistance. Pharmacology Reviews 53 25-71.

Clarke R, Liu MC, Bouker KB, Gu Z, Lee RY, Zhu Y, Skaar TC, Gomez B, O'Brien K, Wang Y et al. 2003 Antiestrogen resistance in breast cancer and the role of estrogen receptor signaling. Oncogene 22 7316-7339.

Dowsett M, Nicholson RI \& Pietras RJ 2005 Biological characteristics of the pure antiestrogen fulvestrant: overcoming endocrine resistance. Breast Cancer Research and Treatment 93 S11-S18.

Fowler AM, Solodin N, Preisler-Mashek MT, Zhang P, Lee AV \& Alarid ET 2004 Increases in estrogen receptor- $\alpha$ concentration in breast cancer cells promote serine 118/104/106-independent AF-1 transactivation and growth in the absence of estrogen. FASEB Journal 18 81-93.

Fowler AM, Solodin NM, Valley CC \& Alarid ET 2006 Altered target gene regulation controlled by estrogen receptor-alpha concentration. Molecular Endocrinology 20 291-301.

Glass CK \& Rosenfeld MG 2000 The coregulator exchange in transcriptional functions of nuclear receptors. Genes and Development 14 121-141.

Howell A 2005 The future of fulvestrant (Faslodex). Cancer Treatment Reviews 31 S26-S33.

Jakowlew SB, Breathnach R, Jeltsch J-M, Masiakowski P \& Chambon P 1984 Sequence of the pS2 mRNA induced by estrogen in the human breast cancer cell line MCF-7. Nucleic Acid Research 12 2861-2877.

Johnston SRD \& Dowsett M 2003 Aromatase inhibitors for breast cancer; lessons from the laboratory. Nature Reviews of Cancer 3 821-831.

Johnston SR, Martin LA \& Dowsett M 2005 Life following aromatase inhibitors-where now for endocrine sequencing. Breast Cancer Research and Treatment 93 S19-S25.

Kuske B, Moore K, MacLeod K, Naughton C, Miller WR, Smyth JF, Clarke R, Cameron DA \& Langdon SP 2004 Estrogen-insensitive MCF-7 breast cancer cells show differential reduced DNA binding and estrogen receptor phosphorylation. Breast Cancer Research and Treatment 88 S178.
Lannigan D 2003 Estrogen receptor phosphorylation. Steroids 68 1-9.

Leu Y-W, Yan PS, Fan M, Jin VX, Liu JC, Curran EM, Welshons WV, Wei SH, Davuluri RV, Plass C et al. 2004 Loss of estrogen receptor signaling triggers epigenetic silencing of downstream targets in breast cancer. Cancer Research 64 8184-8192.

Martin MB, Franke TF, Stoica GE, Chambon P, Katzenellenbogen BS, Stoica BA, McLemore MS, Olivo SE \& Stoica A 2000 A role for Akt in mediating the estrogenic functions of epidermal growth factor and insulin-like growth factor I. Endocrinology 141 4503-4511.

Martin LA, Farmer I, Johnston SRD, Ali S, Marshall C \& Dowsett M 2003 Enhanced estrogen receptor (ER)a, erbB2, and MAPK signal transduction pathways operate during the adaption of MCF-7 cells to long term estrogen deprivation. Journal of Biological Chemistry 278 30458-30468.

Martin LA, Farmer I, Johnston SR, Ali S \& Dowsett M $2005 a$ Elevated ERK1/ERK2/estrogen receptor crosstalk enhances estrogen-mediated signaling during long-term estrogen deprivation. Endocrine-Related Cancer 12 S75-S84.

Martin LA, Pancholi S, Chan CM, Farmer I, Kimberley C, Dowsett M \& Johnston SR $2005 b$ The anti-oestrogen ICI 182,780 , but not tamoxifen, inhibits the growth of MCF-7 breast cancer cells refractory to long-term oestrogen deprivation through down-regulation of oestrogen receptor and IGF signalling. Endocrine-Related Cancer 12 1017-1036.

Masiakowski P, Breathnack R, Bloch J, Gannon F, Krust A \& Chambon P 1982 Cloning of cDNA sequences of hormonregulated genes from the MCF-7 human breast cancer cell line. Nucleic Acid Research 10 7895-7903.

Metivier R, Penot G, Hubner MR, Reid G, Brand H, Kos M \& Gannon F 2003 Estrogen receptor alpha directs ordered, cyclical and combinatorial recruitment of cofactors on a natural target promoter. Cell 115 751-763.

Nardulli AM, Greene GL, O’Malley BW \& Katzenellenbogen BS 1988 Regulation of progesterone receptor message ribonucleic acid and protein levels in MCF-7 cells by estradiol: analysis of estrogen's effect on progesterone receptor synthesis and degradation. Endocrinology 122 935-944.

Nawaz Z, Lonard DM, Dennis AP, Smith CL \& O’Malley BW 1999 PNAS 96 1858-1862.

Nicholson RI, Hutcheson IR, Britton D, Knowlden JM, Jones HE, Harper ME, Hiscox SE, Barrow D \& Gee JM 2005 Growth factor signalling networks in breast cancer and resistance to endocrine agents: new therapeutic strategies. Journal of Steroid Biochemistry and Molecular Biology 93 257-262.

Normanno N, Di Maio M, De Maio E, De Luca A, de Matteis A, Giordano A, Perrone F \& NCI-Naple Breast Cancer 
Group 2005 Mechanisms of endocrine resistance and novel therapeutic strategies in breast cancer. EndocrineRelated Cancer 12 721-747.

Parker MG 1993 Action of pure anti-estrogens in inhibiting estrogen receptor action. Breast Cancer Research and Treatment 26 131-137.

Robertson JF 2002 Estrogen receptor downregulators: new antihormonal therapy for advanced breast cancer. Clinical Therapeutics 24 A17-A30.

Santen RJ, Song RX, Zhang Z, Kumar R, Jeng M-H, Masamura A, Lawrence J, Jr, Berstein L \& Yue W 2005 Long-term estradiol deprivation in breast cancer cells up-regulates growth factor signaling and enhances estrogen sensitivity. Endocrine-Related Cancer 12 S61-S73.

Thorpe SM, Christensen IJ, Rasmussen BB \& Rose C 1993 Short recurrence-free survival associated with high oestrogen receptor levels in the natural history of premenopausal primary breast cancer. European Journal of Cancer 29A 971-977.

Yue W, Wang JP, Conaway M, Masamura S, Li Y \& Santen RJ 2002 Activation of the MAPK pathway enhances sensitivity of MCF-7 breast cancer cells to the mitogenic effect of estradiol. Endocrinology 143 3221-3229. 